\title{
Design for AAL Integrated Furniture for the Care and Support of Elderly and Disabled People
}

\section{Dizajn za AAL integrirani namještaj za brigu i pomoć starijim osobama i osobama s invaliditetom}

\author{
Original scientific paper • Izvorni znanstveni rad \\ Received-prispjelo: 30. 9. 2016. \\ Accepted-prihvaćeno: 30. 8. 2017. \\ UDK: 630*79; 630*836 \\ doi:10.5552/drind.2017.1642
}

\begin{abstract}
The European furniture sector is a key driver of sustainable growth, with a significant contribution to Europe's overall economic health, competitiveness, creativity, innovation, employment and exports. It provides 1.08 million jobs to the European economy, and the needs of the European population in the future are one of the key factors of its improvement. By 2050, the number of people in the EU aged 65 and above is expected to grow by $70 \%$ and the number of people aged over 80 by $170 \%$ ! Ambient Assisted Living (AAL) allows people to live at home for longer, despite cognitive or physical impediments. AAL is the answer for the growing elderly population in most European economies, and is a growing sector creating jobs. Furniture for elderly and disabled people needs to be special because of the requirements of its users. Its functionality depends on a good combination of: design and ergonomics, basic electronics, psychology, and $A A L$.
\end{abstract}

Keywords: furniture, $A A L$, ergonomic, design, elderly, disabled people

SAŽETAK • Europski sektor proizvodnje namještaja ključni je pokretač održivog razvoja koji znatno pridonosi i zdravlju ukupnoga europskoga gospodarstva, konkurentnosti, kreativnosti, inovativnosti, zapošljavanju i izvozu. Sektor proizvodnje namještaja osigurava europskom gospodarstvu 1,08 milijuna radnih mjesta, a jedan od ključnih čimbenika poboljšanja stanja u sektoru jesu buduće potrebe europskog stanovništva. Do 2050. godine u EU-u se očekuje porast broja stanovnika u dobi od 65 i više godina za $70 \%$, a stanovnika starijih od 80 godina za 170 \%. Život potpomognut okolinom (Ambient Assisted Living - AAL) omogućuje ljudima da dulje žive kod kuće unatoč njihovim kognitivnim ili fizičkim poteškoćama. AAL je odgovor na sve veći broj starijih osoba u većini europskih gospodarstava te je riječ o sektoru koji stvara nova radna mjesta. Namještaj za starije osobe i osobe s invaliditetom mora biti poseban zbog specifičnih potreba njegovih korisnika. Funkcionalnost tog namještaja ovisi o dobroj kombinaciji dizajna i ergonomije, osnovne elektronike, psihologije i AAL-a.

Ključne riječi: namještaj, Ambient Assisted Living, ergonomija, dizajn, starije osobe, osobe s invaliditetom

\footnotetext{
${ }^{1}$ Authors are assistants and professors at Faculty of Wood Technology, Warsaw University of Life Sciences, Warsaw, Poland.

${ }^{1}$ Autori su asistenti i profesori Fakulteta drvne tehnologije, Sveučilište znanosti o životu u Varšavi, Varšava, Poljska.
} 


\section{INTRODUCTION}

\section{UVOD}

Because of the growing average age of the population, the aspects of Ambient Assisted Living (AAL) are becoming more important. Many companies across Europe are trying to prepare their production system for the possibility of producing AAL integrated furniture. One of the most problematic aspects related to the implementation of AAL integrated furniture concerns the qualifications of employees (f.e. Estaco, Granberg, IKEA, Pegasus Peka, BLUM). This problem has led to the analysis of the need for a Vocational Education Trainings (VET) system in the furniture sector.

The main objective of the study is to address the challenges of the vocational skill mismatch that the new demand for AAL integrated habitats has produced, by the development and validation of a harmonised European Curriculum based on the principles of ECVET in the area of design and manufacture of Smart Support Furniture for Ambient Assisted Living. One of the most important specific objectives of the study is the definition of skills needs in the field of AAL, and requirements for manufacturing Smart Support Furniture for Ambient Assisted Living. The manufacturing covers almost all aspects of technological production, logistics, specific equipment (electronics, functional equipment, etc.), and is especially connected with ergonomic requirements. A VET of manufacturing "ergonomic" furniture for the care and support of elderly and disabled people is especially difficult because furniture is produced by people who do not understand AAL [540016-LLP-1-2013-1-ES-LEONARDO-LMP]. They are just fit, which is why it is necessary to prepare a very detailed handbook for the teaching programme.

\subsection{Universal design philosophy}

1.1. Univerzalna filozofija dizajna

The idea of universal design was born in the 1980s, in the environment of American architects, who decided that buildings should be designed so as to be available to all potential users, including the elderly and disabled. Since then, the concept of universal design has spread worldwide and has influenced and combined related concepts such as Design for AAL, Life Span Design, and Inclusive Design (Duncan, 2015).

The architect Ronald Lawrence Mace was the first to define the concept of universal design; it was he who assumed that "the design of products and environment should be made in such a way that it is usable by all the people, to the greatest possible extent, without the need for adaptation or special design" (Mace, 1988). Nowadays, this concept has become the philosophy and strategy of democratic states, and it is increasingly present in our daily lives.

Universal design applies to both the design of public spaces and industrial facilities. It should be emphasised that universal design is not a set of strictly defined rules and standards, but a concept that assumes that the goal is the largest possible usefulness and flexibility of the achieved results. It should be added that universal design reduces the need for individual facili- ties, but allows them if necessary. The philosophy of universal design - regardless of the field of design - is based on seven key principles (Duncan, 2015):

1) equitable use - it is assumed that the design results will be used by people with very different potential uses;

2) flexibility in use - as far as possible, the design should take into account the preferences of different user groups, e.g. the ability to choose the method of use and adjustment to the different speeds of use of individual users;

3) simple and intuitive - the use of this product should not pose great difficulties, i.e., the principles of use of the product should be understandable regardless of the experience and skillset of the user;

4) perceptible information - ensuring the effective flow of information to the user, regardless of its perceptive abilities;

5) tolerance of error - minimizing the effects of accidental and abnormal activities (such as warning against errors, security in case of failure);

6) low physical effort - reducing the physical effort required to use the design results, such as reducing the number of repetitive activities;

7) size and space for approach and use - it is assumed that the designed product will have the right size, and that space required will be guaranteed in order to get closer to it and handle it, regardless of the posture and mobility of the user.

The aim of applying the rules of universal design is to obtain better solutions in terms of servicing the needs of the user and to ensure its availability to satisfy the user's needs, regardless of physical fitness, skills or knowledge.

Accordingly, universal design is something more than adapting public space to the needs of people with various disabilities - it is a practical implementation of human rights, which prevents discrimination, marginalisation and stigmatisation of people with reduced functionality.

The philosophy of universal design also fits into the design of AAL , which is based on the assumption that the Design for AAL means a design for human diversity, social inclusion and equality. Its essence is to support designs that produce innovative devices for the elderly and disabled (Lusher and Mace, 1989). It also assumes that innovative technological solutions need to be flexible, functional and tailored to individual and changing needs of the elderly and dysfunctional people. These solutions have to be smart to enable living assisted by the environment. This holistic and innovative approach constitutes a creative and ethical challenge for all planners, designers, and entrepreneurs of the furniture industry. The design of AAL furniture can be based on some studies and experiences (BLUM; Jabłoński, 2006; Openshaw and Taylor, 2006; Ramsey, 1999; PMI, 2009).

\subsection{Design for $A A L-a$ challenge for furniture designers of the $\mathrm{XXI}$ century}

1.2. Dizajn za AAL - izazov dizajnerima namještaja 21. stoljeća

In the twenty-first century, increasing competitiveness in the market of furniture manufacturers deter- 
mines the need to seek new market niches allowing for demographic changes, and thus the need to introduce a design for AAL philosophy. This is primarily related to the aging population in Europe, and the increase in the average length of human life. In Poland, for example, demographic forecasts predict that the proportion of the elderly in the population structure will reach 22.3 $\%$ in 2030, and as many as $35.6 \%$ in 2050 (***GUS; ***NSP, 2011; St.gov.). Secondly, the number of people with disabilities is increasing year by year.

It is currently estimated that there are about 500 million disabled people in the world. In Poland alone, there are about four million (including two million disabled people over 65 years old). It is, therefore, worth considering the situation of these people and trying to determine what problems and difficulties they face every day, and in what way custom-designed furniture can help them in everyday life.

Unfortunately, in Poland there is still no real long-term approach or focusing on the production of furniture for older consumers, or people with disabilities. Furniture manufacturers have limited knowledge of the needs of the elderly and disabled, and very often they do not understand these people's relationship with furniture. Designing for this group is too often based on generalisations that do not meet their needs and desires. Moreover, as research shows - it is a mistake to consider the elderly and disabled as a homogeneous group and to define their needs in advance, because among them there is a large diversity in relation to the expectations, needs and wishes regarding furniture. The needs expressed by older people themselves are different from the existing recommendations for furniture designed for the elderly. The latter are based primarily on the effects of physiological changes of the elderly and disabled. They provide support also for psychological and social changes. According to the idea of design for AAL, one should merely assume that the furniture should provide comfort, pleasure and independence. Designers should be closely involved in researching the needs and expectations of older people and take a holistic view of people and their different needs that match their individual identity (Jonsson, 2013; Charytonowicz, 1998).

In Poland, most furniture manufacturers do not have skilled workers to design and manufacture products taking into account the needs of the elderly and disabled. It is, therefore, necessary to develop a coherent curriculum in this area that would allow adequate knowledge, personal and professional competencies, to be achieved, and thus introduce the AAL philosophy in the furniture industry. First and foremost, they should be familiar with the concept of universal design and AAL, as well as with the needs and disabilities of the elderly and disabled. They must be able to classify types and degrees of disability, and to know the basics of formal and legal rules for persons with disabilities (system solutions) - in order to be able to determine both the design and the price or distribution. For example, in Poland, subsidies for the elimination of barriers have been envisaged by the State Fund for the Reha- bilitation of the Disabled (***PFRON) or by the District Family Assistance Center (***PCPR).

The concept covers the adaptation of kitchen furniture, bathroom customisation and renovation or replacement of old windows, adaptation, building ramps and handrails, etc. Subsidies can reach up to $80 \%$ of investment costs, but not more than fifteen times the average salary (***MOPS).

The knowledge is also critical of the requirements of designing the environment for persons with disabilities, ergonomic design criteria and familiarity with matters relating to the anthropometric rules shaping the work and life environment of the elderly and disabled. Designs must take into account both the needs and functionality, but also the legal requirements and safety standards laid down for the European and international markets (CE mark, ISO standards, etc).

In designing the environment of persons with disabilities and elderly people, it is also important to develop in oneself the ability of practical application of the above-mentioned requirements and master the principles of interior organization, as well as focus on the user.

\subsection{Design adapted to needs - the AAL psychology}

1.3. Dizajn prilagođen potrebama - psihologija AAL-a

Psychology, being connected to investigating mechanisms and rules governing psychological and human behaviour, constitutes a part of necessary competencies of people with professional interests in design, furniture manufacturing and creating space for the elderly and disabled. Furniture manufacturers who understand the needs of older and disabled people can, while using the current knowledge and technology, excellently fit into the market and, thanks to their products, make everyday life of the elderly and disabled easier - all of this makes AAL psychology. Therefore, taking account the knowledge in this field is an important element in training the design and production of specialised furniture for the elderly and disabled. Building on this knowledge, training participants are open to the needs and expectations of older and disabled people, and when involved in design, they will do their best to improve the life-quality of the elderly and people with disabilities in accordance with the AAL psychology. It could be said that AAL psychology means an informed analysis of the needs of the elderly and disabled; in design, it sets comfort, safety and flexibility as a priority, and it requires the involvement of end-users at every stage of the design process. This type of psychology also provides information as regards users' needs, motivations and tastes, as well as behaviours, and it answers questions, such as: how do consumers accept technology and use it? Or: how to prepare an appropriate offer and appeal to the elderly and disabled with advertising.

It is worth keeping in mind that the need to have a place to live, be it a flat or a house, is one of the crucial needs. While aging, people want to be self-reliant for as long as possible, and are reluctant to change the environment, and in particular their place of residence. Fully 
agile adults need no special adaptation of the surrounding space, whereas the elderly - most often those with reduced mobility - need a special adaptation of their residence place to their needs. The disability of the motor system is a reason for requiring more space for moving and manoeuvring. In addition, older users also require a completely different approach to design. What they primarily expect is: functionality, safety and comfort in moving. For people moving with difficulty, the appropriate selection and set-up of furniture is pivotal. It is also important to make it easy to open cabinets, store and search for things that should be at arm's reach, equipping a flat with specialized beds, mattresses, bedside tables, walking frames, lifters, wheelchairs or chairs (Nowakowski and Charytonowicz, 2001). For the elderly, the furniture's material is also important; materials should have high durability and long-term usefulness. Furthermore, while aging, people tend to focus more on aesthetics and quality than on current fashion trends.

The constantly increasing number of people with limited ability has made integration aspects in creating flats become a requirement throughout society, and ensuring optimum conditions for satisfying qualitative housing needs relates to a specific flat standard. Therefore, furniture for the disabled should be equipped with special handholds and cavities that make it easy for a disabled person to use the furniture, while adapting to the person's needs and the level of motor ability. Primarily, it must be much lower than standard furniture. Such furniture could be aesthetic, nice-looking and modern, while at the same time it should be well thought out and ergonomic (Sawczuk, 2014; Ślusarczyk, 2015). For instance, modular furniture is a good solution. Enterprises that produce furniture for the disabled in order to address the needs of those with disabilities may design cabinets on wheels, for instance, to make them more easily movable; corner cupboards with revolving shelves to make windows easily accessible; cargo-cabinets that can be ejected on guide rails and thus make their contents easily accessible without the need to bend to get to what is inside. A very useful and comfortable convenience is that of telescope hanger systems with hangers that can easily be pulled to one another, upper cabinets on vertical guide rails or kitchen tables with seats that can be ejected. In addition, special railings and strips securing tables and preventing objects from falling are applied (for more information on this topic, the authors recommend further references, such as: Kmiecik and Tytyk, 2001).

Older consumers will begin to increasingly matter on the market - and it should be remembered that they will also become increasingly demanding. According to the AAL philosophy, older people deserve better designs for living, whereas the industrial designs intended for them have to date been dull, with grim design prevailing, and quite little product range (Burke, 2012).

So there is a great potential for innovation in this field. It is an issue being dealt with not only by entrepreneurs, but also by scientists, since it involves looking for appropriate forms and materials that are more user-friendly for the elderly. The Blum Company, for instance, currently the most advanced innovative company in the field of kitchen furniture - makes use of special suits stimulating the movements of an older person in addressing the needs of the elderly while designing kitchen rooms (BLUM). One of the five key areas of the international StarDust project, in turn, is focused on designing products for the elderly. Advanced research related to designing multi-functional kitchens for older people is being conducted (STARDUST) as part of the "Comfort in Living” concept. Then there is IKEA, which - as early as in 2010 - created a visualisation entitled SKARP, showing a kitchen of the future in 2040. The visualisation was created on the basis of answers by two thousand respondents, who were to write how they imagined a kitchen would look like in thirty years, with solutions proposed excellently fitting in the universal design and the AAL philosophy.

In general, every piece of furniture, equipment, etc. surrounding people has already been designed. It is the manner in which the process has developed that determines the comfort of people's lives, and in many cases also the fact whether they will be able to make active use of it.

\subsection{Anthropometrics and ergonomics \\ 1.4. Antropometrija i ergonomija}

Anthropometry data for design - the sitting position is presented in Figure 1. The body dimensions in the sitting position of the working age population in Poland, useful in designing office furniture (in $\mathrm{mm}$ ), are shown in Table 1, together with explanations of symbols. Data on the dimensions of society are defined by lower percentile values (C5), the value of the median (average) percentile (C50) and the upper percentile (C95). This means that the values determined by C5 do not reach $5 \%$ of the population of a given society, and that a majority of the population

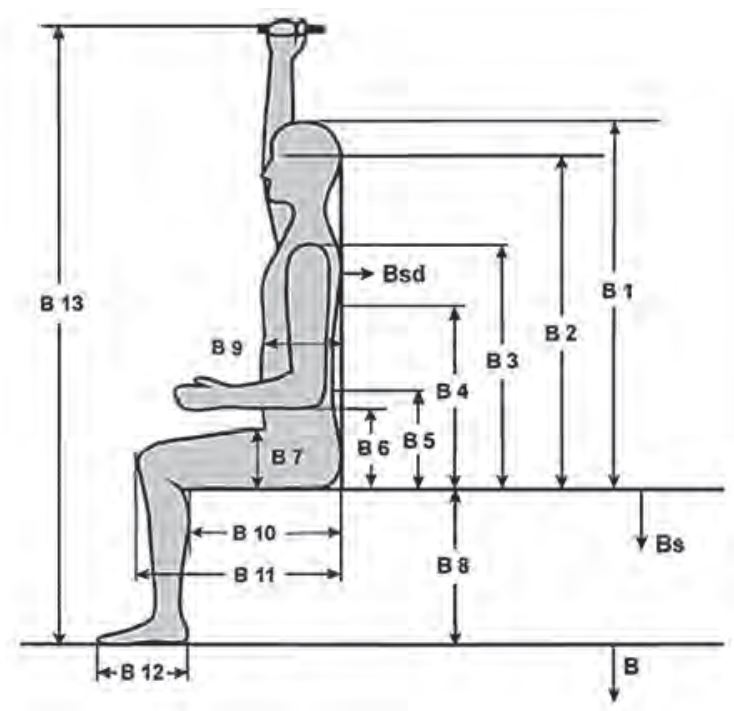

Figure 1 Anthropometry data for design - sitting position (***IWP; ***CIOP)

Slika 1. Antropometrijski podatci za dizajn - sjedeći položaj (*** IWP; *** CIOP) 
Table 1 Body dimensions in sitting position (***IWP; ***CIOP)

Tablica 1. Dimenzije tijela u sjedećem položaju (***IWP; ***CIOP)

\begin{tabular}{|c|c|c|c|c|c|}
\hline \multirow{2}{*}{$\begin{array}{c}\text { Feature } \\
\text { symbol } \\
\text { Oznaka } \\
\text { obilježja }\end{array}$} & \multirow{2}{*}{$\begin{array}{l}\text { Feature } \\
\text { Obilježje }\end{array}$} & \multicolumn{2}{|c|}{ Male / Muškarci } & \multicolumn{2}{|c|}{ Female / Žene } \\
\hline & & C5 & C95 & C5 & C95 \\
\hline B1 & Sitting height / visina sjedenja & 833 & 980 & 792 & 916 \\
\hline $\mathrm{B} 2$ & Eye height / visina očiju & 711 & 840 & 691 & 781 \\
\hline B3 & Midshoulder height / visina sredine ramena & 547 & 668 & 515 & 625 \\
\hline B4 & Subscapular height / visina podlopatice & 364 & 531 & 350 & 489 \\
\hline B5 & Lumbar height / visina lumbalnog područja & 115 & 171 & 115 & 169 \\
\hline B6 & Elbow rest height / visina lakta & 194 & 301 & 198 & 292 \\
\hline B7 & Thigh clearance / visina bedra & 115 & 171 & 115 & 169 \\
\hline B8 & Popliteal height / visina poplitealne udubine & 388 & 488 & 361 & 448 \\
\hline B9 & Body depth / dubina tijela & 230 & 344 & 197 & 343 \\
\hline B10 & Popliteal length (seat depth) / poplitealna duljina (dubina sjedala) & 480 & 588 & 441 & 552 \\
\hline B11 & Knee length / duljina koljena & 554 & 646 & 532 & 624 \\
\hline B12 & Foot dimension / dimenzija stopala & 250 & 284 & 221 & 257 \\
\hline B13 & Vertical reach height / visina vertikalnog dosega & 1181 & 1382 & 1097 & 1278 \\
\hline
\end{tabular}

a)

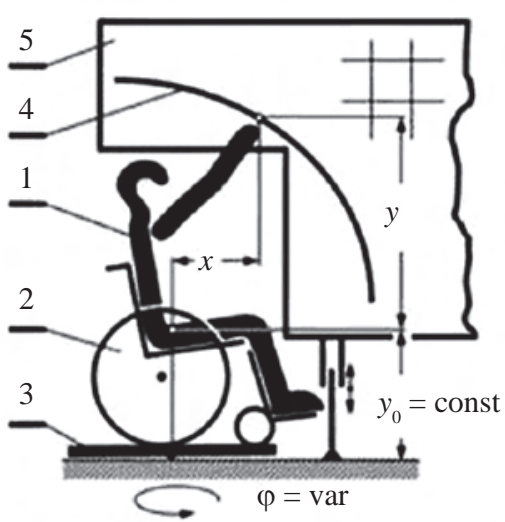

b)

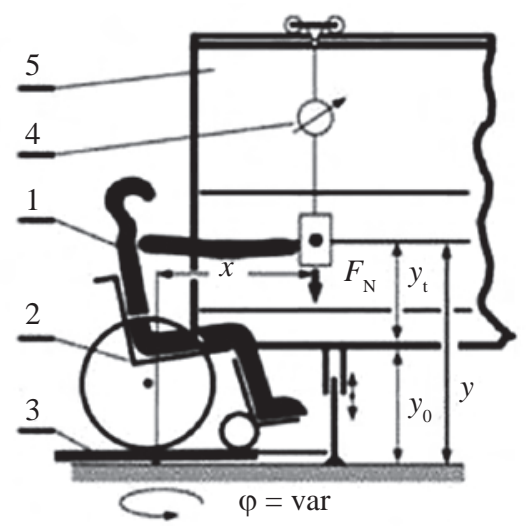

Figure 2 Block diagram of a measurement stand and method of arm reaches (a) and arm forces (b) of a disabled person sitting in a wheelchair in a 3D space of geometrical dimensions $x, y, z$ : (1) - handicapped person; (2) - active wheelchair; (3) - measuring protractor, (4) - reach curve (a) or measuring dynamometer (b); (5) - table (***what-when-how.com) Slika 2. Blok-dijagram mjernog stalka, (a) metode dosega ruke i (b) ručne sile osobe s invaliditetom koja sjedi u invalidskim kolicima u 3D prostoru geometrijskih dimenzija $x, y, z$ : 1 - osoba s invaliditetom; 2 - aktivna invalidska kolica; 3 - mjerač kuta, 4 - krivulja dosega (a) ili mjerni dinamometar (b); 5 - tablica (***what-when-how.com)

(90\%) is below the value specified by C95. For this reason, furniture and items intended for an anonymous client are designed for people falling in the interval between C5 and C95.

Analogously, there are studies of anthropometry data of design for people in wheelchairs (Figure 2). This data contains block diagrams of a measurement stand and the method of arm reaches.

For people in wheelchairs, there are facilities that enable them to reach all furniture. Figures 3 and 4 show proposals of design and functional solutions.

The goal of the studies was to analyse the needs of vocational education in the furniture sector, which will be adapted to the production of AAL furniture. This paper focuses on the vocational education of workers of various degrees of responsibility in the company's furniture design. In the project, they were divided into four groups: blue collar worker, designer/ engineer, freshman, manager. Since all of these groups have other duties in the manufacturing process, it was

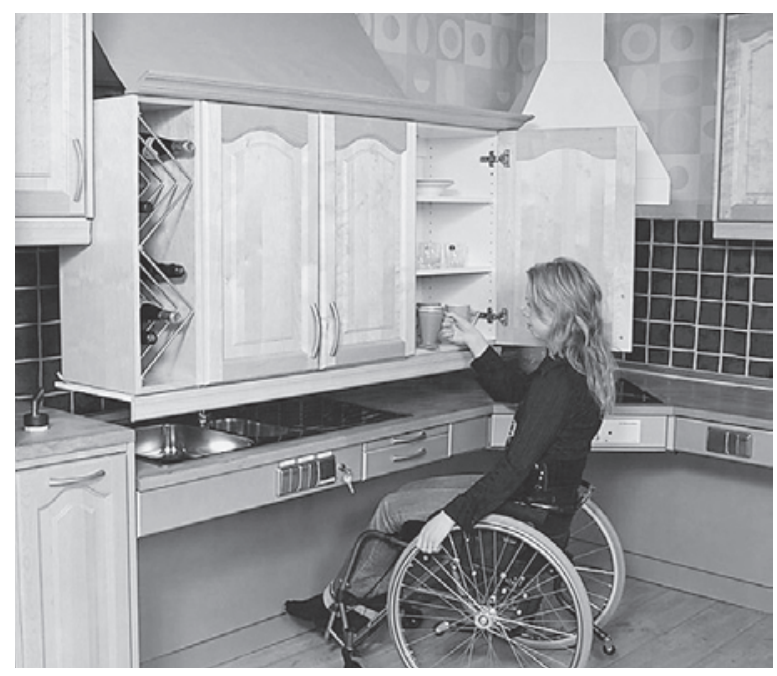

Figure 3 Facility to reach upper cabinets 1 (***GRANBERG)

Slika 3. Instalacija za dosezanje gornjih ormara 1 (*** GRANBERG) 


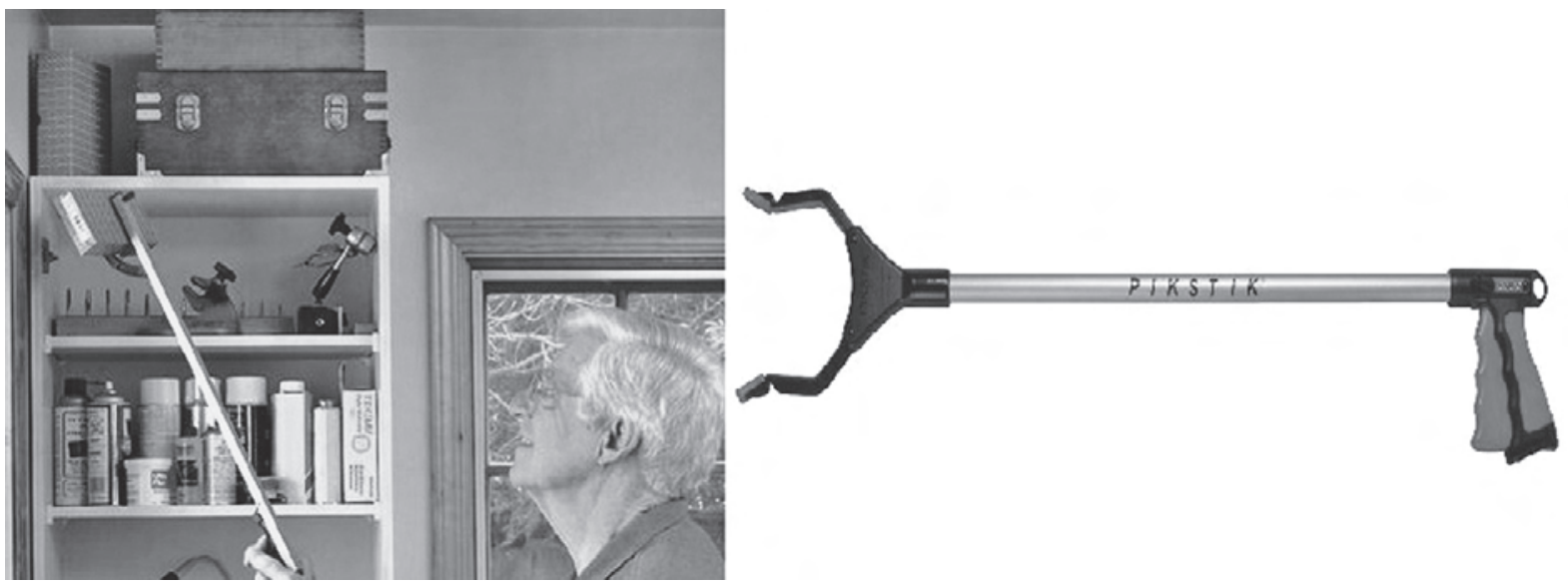

Figure 4 Facility to reach upper cabinets 2 (***AZZURRO DESIGNE)

Slika 4. Naprava za dosezanje gornjih ormara (***AZZURRO DESIGNE)

necessary to define various methods of Vocational Education Trainings (VET).

\section{MATERIALS AND METHODS 2. MATERIJAL I METODE}

The first task in the analysed project was to determine the Skills, Knowledge and Competences (SKC) of producers, who manufacture furniture for the elderly and disabled people. For this purpose, a questionnaire was created for all pillars: the Basic concepts of electronics, Psychology, Design and Ergonomics, Ambient Assisted Living. The questions were directed to groups of furniture employers working in different positions: blue collar, designer and manager.

Each part of the questionnaire consisted of five yes/no questions and two open questions. The main aim of the questionnaire was to obtain information about the experience of workers in various fields: Design and Ergonomics, Basic Electronics, Psychology and the needs of the elderly and disabled, Ambient Assisted Living and its integration in furniture.

The questions about Design and Ergonomics were drawn up by Polish partners and then corrected by partners from five European countries. The questionnaire was then carried out and analysed in the countries of the main partners: Spain, Slovenia and Poland. The questions asked, and then analysed, were those presented in Table 2.

\section{RESULTS AND DISCUSSION}

3. REZULTATI I RASPRAVA

After receiving the answer from all the partners (respondents from 25 Polish companies, 19 Spanish companies and 8 Slovenian companies), the national qualification profiles developed were analysed and the desk research was conducted. The analysis was done by counting the percentage of people who correctly answered the questions, which means the answers YES to each question. The results are presented in Figure 5. The questionnaire was also the basis for creating the first draft of an e-learning platform for furniture workers.

The results of the studies presented in Figure 5 show that most furniture companies in Poland, Spain and Slovenia agree that their knowledge about furniture production for the elderly and disabled is insufficient to be competitive on this market. They also agree

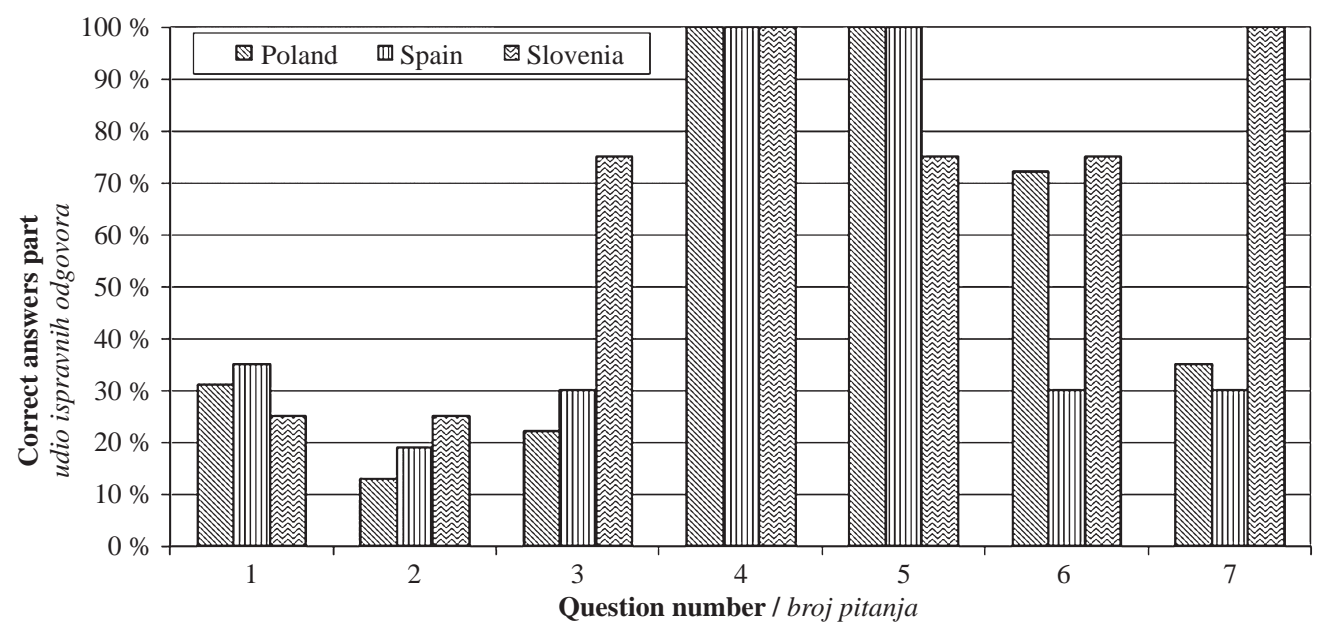

Figure 5 Questions summary about design and ergonomics (the share of correct answers - the answer YES to each question) Slika 5. Sažetak rezultata upitnika o dizajnu i ergonomiji (ispravnima su smatrani upitnici s odgovorom „da” na svako pitanje) 
Table 2 Questions about design and ergonomics

Tablica 2. Pitanja o dizajnu i ergonomiji

\begin{tabular}{|c|c|c|}
\hline No & Question / Pitanje & $\begin{array}{c}\text { Type of answer } \\
\text { Odgovor }\end{array}$ \\
\hline 1. & $\begin{array}{l}\text { Is your company (or you) familiar with design and ergonomics for alder and disabled people to } \\
\text { become competitive on this market? } \\
\text { Je li vaša tvrtka (ili vi) upoznata s dizajnom i ergonomijom za starije osobe i osobe s invaliditetom } \\
\text { kako bi postala konkurentnija na tržištu? }\end{array}$ & $\begin{array}{l}\text { yes/no } \\
d a / n e\end{array}$ \\
\hline 2. & $\begin{array}{l}\text { Do your company’s designers and/or constructors already deal with furniture designated for elderly } \\
\text { and disabled people? } \\
\text { Bave li se već sad dizajneri i/ili projektanti vaše tvrtke namještajem namijenjenim starijim osobama } \\
\text { i osobama s invaliditetom? }\end{array}$ & $\begin{array}{l}\text { yes/no } \\
d a / n e\end{array}$ \\
\hline 3. & $\begin{array}{l}\text { Do you plan to educate your workers responsible for design and construction for elderly and } \\
\text { disabled people? } \\
\text { Planirate li dodatno obrazovati svoje radnike zadužene za dizajn i projektiranje namještaja za } \\
\text { starije osobe i osobe s invaliditetom? }\end{array}$ & $\begin{array}{l}\text { yes/no } \\
\text { da/ne }\end{array}$ \\
\hline 4. & $\begin{array}{l}\text { Do you think that a competent institution should undertake the task of collecting anthropometric } \\
\text { data on statistically representative group of elders in your country (males and females, aged } 65 \text { and } \\
\text { above)? Could such data be used in design of a variety of products, furniture and utilities? } \\
\text { Mislite li da bi relevantna institucija trebala provesti projekt prikupljanja antropometrijskih } \\
\text { podataka na statistički reprezentativnoj skupini starijih osoba u vašoj zemlji (muškaraca i žena u } \\
\text { dobi od } 65 \text { i više godina)? Mogu li se takvi podatci koristiti pri dizajniranju različitih proizvoda, } \\
\text { namještaja i komunalnih usluga? }\end{array}$ & $\begin{array}{l}\text { yes/no } \\
d a / n e\end{array}$ \\
\hline 5. & $\begin{array}{l}\text { Do you think that designers of elderly-oriented furniture should be aware of other implications of } \\
\text { their tasks, such as flooring, lighting, signs, etc. with the aim of creating older user-friendly interior } \\
\text { environment? } \\
\text { Mislite li da bi dizajneri namještaja za starije osobe trebali biti upoznati s drugim činiteljima koji } \\
\text { utječu na okolinu starijih osoba kao što su podovi, rasvjeta, znakovi itd. radi stvaranja interijera } \\
\text { prilagođenih starijim korisnicima? }\end{array}$ & $\begin{array}{l}\text { yes/no } \\
\text { da/ne }\end{array}$ \\
\hline 6. & $\begin{array}{l}\text { Is it reasonable to reconsider ageing process in contemporary society, which changed a lot through } \\
\text { recent years due to new communication possibilities (internet) and other social changes? } \\
\text { Je li razumno ponovo razmotriti proces starenja u suvremenom društvu jer se on tijekom posljednjih } \\
\text { godina mijenja zbog novih komunikacijskih mogućnosti (interneta) i drugih društvenih promjena? }\end{array}$ & $\begin{array}{l}\text { yes/no } \\
d a / n e\end{array}$ \\
\hline 7. & $\begin{array}{l}\text { If you consider education of workers on the above topics, what would be your preferred teaching } \\
\text { type: short courses, periodical meetings and workshops, lifelong learning centers, or maybe some } \\
\text { other ideas? } \\
\text { Ako smatrate potrebnim obrazovati radnike o navedenim temama, koju biste vrstu poučavanja } \\
\text { izabrali: kratke tečajeve, periodične sastanke i radionice, centre za cjeloživotno učenje? Ili možda } \\
\text { imate neke druge ideje? }\end{array}$ & $\begin{array}{c}\text { Open } \\
\text { otvoreno }\end{array}$ \\
\hline
\end{tabular}

that most of their constructors and designers have no experience in designing furniture with the elderly and disabled in mind.

Answering the question 3, most furniture companies in Poland (22 \%) and Spain (30\%) admitted that they did not plan to educate their workers in analysing the manufacturing sector. Only Slovenian companies (75 \%) believed that furniture for elderly and disabled was a sector that they wanted to develop in their production companies, and they saw a need for additional education training for workers.

In any case, all the companies in the analysed countries see the need to collect anthropometric data about people over 65. The answers to this question prove that all furniture companies are in fact thinking about the concerned market as one that will develop and can be an interesting sector in their future production. Furthermore, most of the companies in the analysed countries believe that well-designed furniture for the elderly should be accompanied with implications such as flooring, lighting, signs, etc. with the aim of creating user-friendly interior environments for the elderly. So, most of the companies think that these aspects do have an influence on well-designed furniture for this group of people.

In Poland and Slovenia, companies think that it is a reasonable process to reconsider the process due to new communication possibilities and other social changes. Only according to the Spanish industry, reconsidering this issue is not relevant to the needs of furniture manufacturing.

According to the responses to the last question, all of the furniture companies in Spain think that their workers should take training in designing furniture for the elderly and disabled. Most of the companies in Poland and Slovenia do not see any such need for their workers. In any case, all the companies that are interested in such education answered that they would prefer short-term courses or periodical meetings with workshops. This can be interpreted as follows: if a company decided to invest in additional education of workers, it would like to see the effects as soon as possible. 


\section{CONCLUSIONS}

\section{ZAKLJUČAK}

Demographic changes in this century, in combination with a growing number of people with disabilities and legal requirements on design, are changing design requirements, creating new challenges for furniture designers. On the one hand, their products should be primarily useful, so that they can be enjoyed to the greatest possible extent by everyone, regardless of age, ability, or status in life. On the other hand, the transformation of thinking about old age and disability should contribute to improve the quality of life of these consumers, by implementing Ambient Assisted Living (AAL) design philosophy - namely, designing individual and smart solutions for ambient assisted living. Therefore, training and specialisations, taking into account universal design issues and AAL in their programmes and curricula, are necessary. When designing, designers must be familiar with the guidelines for adapting architectural objects and furniture to the needs of people with various types of disabilities and the needs of the elderly. This requires interdisciplinary knowledge that includes, on the one hand, ergonomic issues, anthropometric research and computer aided design, and issues related to gerontology and social policy, on the other hand.

Analyses show that furniture designed with the elderly and disabled in mind is becoming a market that will develop over the next few years. Companies are aware of this trend and they see the need for changes in their production systems, so they can be adaptable to the needs of elderly people.

\section{Acknowledgement - Zahvala}

This study is financially supported by the Ministry of Science and Higher Education with project No. 3026/LLP/13/2014/2 and by EU with project No. 540016-LLP-1-2013-1-ES-LEONARDO-LMP (www. vetaal.eu)

\section{REFERENCES}

\section{LITERATURA}

1. Charytonowicz, J., 1998: Preventive care in the development of the home furniture (Profilaktyka zdrowotna w kształtowaniu meblarskiego wyposażenia Mieszkania), Lodz: Materials of the International Conference on Ergonomics for Disabled - MKEN (Łódź: Materiały Międzynarodowej Konferencji „Ergonomia Niepełnosprawnym - MKEN"), pp. 35-41.

2. Górska E., 2002: Job unit design for disabled (Projektowanie stanowisk pracy dla osób niepełnosprawnych) Publishing House of Warsaw University of Technology, Warsaw Oficyna Wydawnicza Politechnika Warszawskiej, Warszawa.

3. Jabłoński, J., 2006: Ergonomics. Ergonomic principles of product design (Ergonomia produktu. Ergonomiczne zasady projektowania produktów), Poznan, Published by Poznan University of Technology, Poznań, Wydawnictwo Politechniki Poznańskiej.

4. Lusher, H.; Mace, R., 1989: Design for Physical and Mental Disabilities. In: Encyclopaedia of Architecture:
Design Engineering and Construction, ed. J. Wilkes and Sons, 3.

5. Mace, R., 1988: Universal Design, In: Designers West, p. 4.

6. Nowakowski, P.; Charytonowicz, J., 2001: Selected problems of environmental quality of life of people with disabilities (Wybrane problemyjakości środowiska życia osób niepełnosprawnych), Faculty of Architecture of the Wroclaw Institute of Technology (Wydział Architektury Politechniki Wrocławskiej), MKEN, Wroclaw.

7. Openshaw, S.; Taylor, A. E., 2006: Ergonomics and Design a Reference Guide. Allsteel Inc.

8. Ramsey, C. G., 1999: Architectural Graphic Standards, Tenth Edition, The American Institute of Architects, John Ray Hoke, Jr. Editor in Chief, (c) John Wiley \& Sons, Inc.

9. PMI, 2009. A Guide to the Project Management Body of Knowledge, Fourth Edition, Project Management Institute.

10. ${ }^{* * *}$ 1997: Polish Act of 27 August 1997. on Social and Professional Rehabilitation and Employment of Disabled (Journal of Laws of 2011. No. 127, item. 721j.t.).

11. ***2001: Kmiecik, K.; Tytyk, E.: Creating quality of living of the elderly and the disabled in the old people's homes. http://idn.org.pl/Lodz/Mken/Mken\%202001/ Referaty\%202001/22.pdf. First published in 2001 (Accessed on 15 December 2015).

12. ***2012: Burke, L.: The old and the disabled usually have to choose from the dull and dreary walking aid and other support products, [in:] Guardiana Professional see: http://www.theguardian.com/social-care-network/2012/ feb/22/adult. First published on 22 February 2012 (Accesed March 2016).

13. ***2013: Jonsson, N.: Furniture for Later Life: Design Based on Older People's Experiences of Furniture in Three Housing Forms. First published 2013 (Accessed 15 December 2015).

14. *** 2014: Sawczuk, P.: Meble dla niepełnosprawnych życie bez barier (Furniture for disabled - life without barriers), First published on 18 March 2014 (Accessed on December 2015).

15. $* * * 2015$ : Report from realization of 540016-LLP-12013-1-ES-LEONARDO-LMP project. First published on December 2015 (Accessed on March 2016).

16. $* * * 2015$ : Duncan, R.: Universal Design, http://universaldesign.ie/What-is-Universal-Design/Conference-Proceedings/Universal-Design-for-the-21st-Century-IrishInternational-Perspectives. First published on September 2015 (Accesed 10 November 2015).

17. ${ }^{* * * 2015: ~ S ́ l u s a r c z y k, ~ C .: ~ U n i v e r s a l ~ d e s i g n ~ i n ~ e d u c a t i o n ~}$ (Projektowanie uniwersalne w edukacji), First published on November 2015 (Accessed 20 December 2015).

18. ***AZZURRO DESIGNE - www.meblekuchenne.pl

19. $* * *$ BLUM - http://blum.eu

20. ***BLUM - http://dynamicspace.com

21. ***CIOP - Central Institute for Labour Protection - National Research Institute, www.ciop.pl

22. ***DP - DISABILITY PRODUCTS - www.disabilityproducts.com

23. ***GRANBERG - www.granberg.se

24. ${ }^{* * *}$ GUS - Main Statistical Office (Główny Urząd Statystyczny), http://www.stat.gov.pl

25. ***Stat. gov. - http://stat.gov.pl/obszary-tematyczne/ ludnosc/ludnosc/sytuacja-demograficzna-osob-starszych-i-konsekwencje-starzenia-sie-ludnosci-polski-wswietle-prognozy-na-lata-2014-2050,18,1.html

26. ***UD - http://www.universaldesign.com/about-universal-design.html

27. ***https://lup.lub.lu.se/search/publication/4146752

28. ***IWP - www.iwp.com.pl 
Beer, Olenska, Podobas, Zbiec: Design for AAL Integrated Furniture for the Care...

29. ***MOPS- Municipal Office for Social Help (Miejski Ośrodek Pomocy Społecznej) - http://www.mops.com. $\mathrm{pl} /$ ?pid $=191$

30. ***NSP - National Census (Narodowy Spis Powszechny), 2011 - http://stat.gov.pl/spisy-powszechne/nsp-2011/

31. ***PCPR- http://www.pcpr.info

32. ***PFRON - State Fund for Rehabilitation of Disabled (Państwowy Fundusz Rehabilitacji Osób Niepełnosprawnych) http://www.pfron.org.pl

33. ${ }^{* * *}$ STARDUST - http://www.bsrstars.se/stardust/aboutstardust/

34. ***VET - http://www.vetaal.eu

35. ${ }^{* * *}$ what-when-how.com/universal-access-in-humancomputer-interaction-uahci-2011/integral-model-of-thearea-of-reaches-and-forces-of-a-disabled-person-withdysfunction-of-lower-limbs-as-a-tool-in-virtual-assess- ment-of-manipulation-possibilities-in-selected-work-environments-unive/

\section{Corresponding address:}

Prof. PIOTR BEER, Ph. D.

Faculty of Wood Technology, Warsaw University of Life Sciences

Department of Technology and Enterpreneurship in Furniture Industry

Nowoursynowska Street 159

02-776 Warszawa, POLAND

e-mail: piotr.beer@onet.pl 